Laurence, D. J. R., et al. (1972). Proceedings of the Royal Society of Medicine.

In Press.
LoGerfo, P., Krupey, J., and Hansen, H. J. (1971). Nero England fournal of Medicine, 285, 138 .

LoGerfo, P., LoGerfo, F., Herter, F., Barker, H. G., and Hansen, H. J. (1972). American fournal of Surgery, 123, 127.

Martin, F., and Martin, M. S. (1970). International fournal of Cancer, 6, 352.

Moore, T. L., Kupchik, H. Z., Marcon, N., and Zamchek, N. (1971). American fournal of Digestive Diseases, 16, 1 .

Order, S. E., Porter, M., and Hellman, S. (1971). New England fournal of Medicine, 285, 471.

Purves, L. R., and Geddes, E. (1972). Lancet, 1, 47.
Reynoso, G., et al. (1972). Fournal of the American Medical Association, 220,

Tee, D. E. H., Wang, M., and Watkins, J. (1965). European fournal of Cancer, 1, 315.

Thomson, D. M. P., Krupey, J., Freedman, S. O., and Gold, P. (1969). (1969). Proceedings of the National Academy of Sciences, 64, 161 . Trouillas, P. (1971). Lancet, 2, 552.

Troullas, P. (1971). Lancet, 2, 552. $\mathrm{T}$ (1970) Nature, 227 1249.

Viza, D., Davies, D. A. L., and Harris, R. (1970) Nature, 227, 1249.

ashi, A., Matsuura, Y., Carpenter, C. M., and Hyde, L. (1968). Fournal of the National Cancer Institute, 40, 663.

Zamchek, N., Moore, T. L., Dhar, P., and Kupchik, H. Z. (1972). New England fournal of Medicine, 286, 83.

\title{
Carcinoembryonic Antigen in the Urine of Patients with Urothelial Carcinoma
}

\author{
R. R. HALL, D. J. R. LAURENCE, \\ D. DARCY, \\ U. STEVENS, \\ R. JAMES, \\ S. ROBERTS, \\ A. MUNRO NEVILLE
}

British Medical fournal, 1972, 3, 609-611

\section{Summary}

Increased amounts of carcinoembryonic antigen (C.E.A.) or C.E.A.-like material are found in the urine of many patients with transitional cell carcinomas of the bladder, including those presumed to be at an early stage of development. It is suggested that measurement of urinary C.E.A. is of clinical diagnostic value in the detection and follow-up of urothelial carcinomas.

\section{Introduction}

In the accompanying paper (Laurence et al., 1972) the radioimmunoassay of the carcinoembryonic antigen (C.E.A.) in plasma is shown to be of clinical value in the diagnosis and follow-up of patients with, in particular, carcinomas of the gastrointestinal tract, bronchus, and breast, although such assays have little or no clinical significance as an initial screening test for cancer in general.

C.E.A. was originally thought to be a specific product of endodermally-derived neoplasms (Gold and Freedman, 1965). Accordingly, in view of the embryological origin of the bladder we have investigated the potential value of urinary C.E.A. measurements for the screening, diagnosis, and follow-up of patients suspected of having urothelial carcinoma.

\section{Subjects and Methods}

The C.E.A. content of urine or plasma, or of both, was measured in patients with urothelial (transitional cell) carcinomas, non-urothelial malignant tumours, and various benign, nonurothelial or renal, diseases. All were inpatients or outpatients of the Royal Marsden Hospital. The urinary C.E.A. levels were also measured in healthy subjects aged 16 to 90 years who were members of the staff of the Royal Marsden Hospital or Institute of Cancer Research, or were inpatients of the Royal Hospital,

\footnotetext{
Royal Marsden Hospital and Chester Beatty Research Institute, London S.W.3

R. R. HALL, F.R.C.S., Vandervell Research Fellow

D. J. R. LAURENCE, PH.D., Senior Scientist

D. DARCY, D.PHIL., Senior Lecturer

U. STEVENS, Junior Technical Officer

R. JAMES, B.SC., Junior Technical Officer

S. ROBERTS, Junior Technical Officer

A. MUNRO NEVILLE, M.D., M.R.C.PATH., Clinical Scientist
}

Chelsea, or the Chelsea Hospital for Women, or who attended a general practitioner's surgery for trivial non-urinary complaints.

Plasma samples were obtained as described previously (Laurence et al., 1972). Urine was collected in $20 \mathrm{ml}$ sterile containers. No special precautions were taken, in that samples were not midstream nor were they taken at any particular time of the day. Each specimen was tested for albumin, glucose, and blood and for infection or bacterial contamination by means of dip-inoculum plates (Oxoid), which were incubated at $37^{\circ} \mathrm{C}$ for 24 hours. If significant infection ( $>100,000$ organisms $/ \mathrm{ml}$ ) was found the organisms were identified. Specimens were stored thereafter at $-70^{\circ} \mathrm{C}$ until assay.

Urine samples in $1 \mathrm{ml}$ aliquots were dialysed using cellulose acetate (Visking 8/32) tubing for three hours against phosphatebuffered saline $\mathrm{pH} 7.2,0.01 \mathrm{M}$ in EDTA. Duplicate $(0.2 \mathrm{ml})$ samples of the undialysable portion were then assayed for their C.E.A. content as described previously (Laurence et al., 1972). The results are expressed as ng of C.E.A. per $\mathrm{ml}$ of urine.

\section{Results}

\section{MALE SUBJECTS}

Analysis of the urinary C.E.A. content of healthy control male subjects yielded a mean level of $14 \mathrm{ng} / \mathrm{ml}$, with a coefficient of variation of $1 \cdot 22$. On this basis $35 \mathrm{ng} / \mathrm{ml}$ was chosen as the upper limit of normal in males; $\mathbf{4 2}$ of the $\mathbf{4 6}$ subjects fell below this level (Table I). None of the four control subjects with raised values had clinical evidence of urinary disease. Examination of the C.E.A. values as a function of age of the control subjects failed to show rising titres with increasing age. Of $\mathbf{3 0}$ males with histologically proved active transitional cell carcinomas of the bladder 20 had urinary C.E.A. levels in excess of $35 \mathrm{ng} / \mathrm{ml}$. Fourteen men who had had previously treated carcinomas of the bladder and who at the time of the present study were judged tumour-free cystoscopically and cytologically all had C.E.A. levels within the normal range. Of the seven patients with benign disorders (including peptic ulceration, ulcerative colitis, and urolithiasis) and the 16 with malignant tumours of other systems (including prostate, testis, renal parenchyma, gastrointestinal tract, and skin) only one with colonic diverticulitis and no evidence of urothelial disease had a raised urinary level of C.E.A. Seven of these 16 patients had plasma levels of C.E.A. between $14 \mathrm{ng}$ and $500 \mathrm{ng} / \mathrm{ml}$.

Examination of the high C.E.A. levels given by carcinoma of the bladder according to the clinical stage of the tumour and its 
TABLE I-Urinary C.E.A. Levels in Healthy Subjects and in Association with a Variety of Disorders

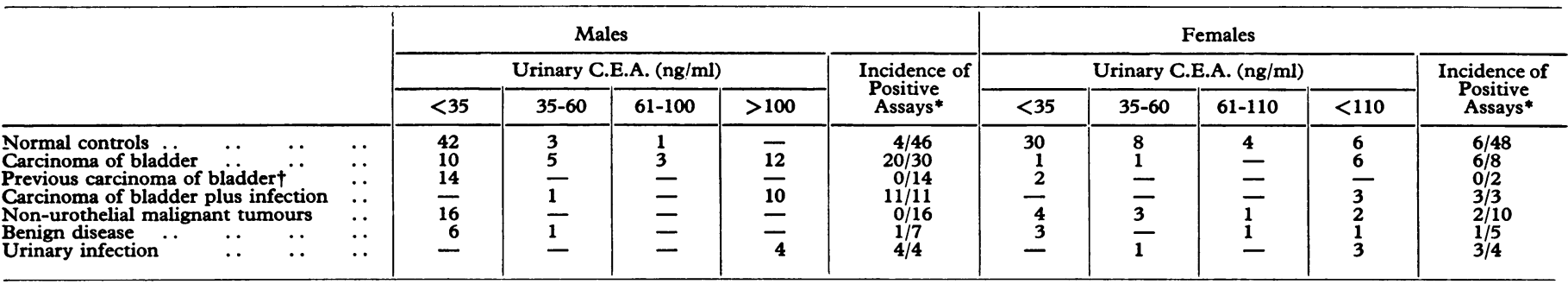

* Upper limit of normal in males is taken as $35 \mathrm{ng} / \mathrm{ml}$ and in females as $110 \mathrm{ng} / \mathrm{ml}$ for random urine specimens.

+ No clinical evidence of recurrent tumour.

morphological differentiation (Table II) showed that the urinary C.E.A. levels were independent of the size and extent of invasion by the tumour and of the degree of differentiation. Some small superficial (T1) tumours could be associated with as high levels of C.E.A. as large invasive (T4) tumours (Table II).

TABLE II-Urinary C.E.A. Levels in Male Patients as Function of Stage and Grade of Transitional Cell Carcinomas

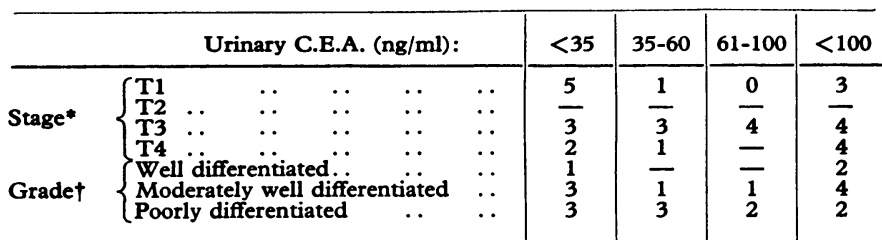

*U.I.C.C. classification.

t Histological data on eight tumours were not available for personal review and those lesions have been omitted.

\section{FEMALE SUBJECTS}

The urinary content of C.E.A. in healthy control females showed a broader distribution of values, with a mean of $47 \mathrm{ng}$ C.E.A. $/ \mathrm{ml}$ and a coefficient of variation of $1 \cdot 29$. This gives an upper limit of normal of $110 \mathrm{ng} / \mathrm{ml}$ (Table I); 6 of the 48 control female subjects had higher levels without evidence of urinary disease.

By selecting the type of urinary sample collected it is possible to show that contamination with either vaginal or cervical secretions or both may account for this difference between normal male and female control values. Fifteen female nurses gave random and then midstream specimens of urine; while the random samples contain a range of C.E.A. levels, one of which was over $110 \mathrm{ng} / \mathrm{ml}$, all midstream specimens contained less than 35 $\mathrm{ng} / \mathrm{ml}$ (Table III). Twenty-six other women with benign nonurothelial disease gave midstream specimens of urine, all of

TABLE III-Urinary C.E.A. levels in Women according to Method of Specimen Collection

\begin{tabular}{|c|c|c|c|c|c|}
\hline \multirow{2}{*}{ Patients } & \multirow{2}{*}{$\begin{array}{l}\text { Type of } \\
\text { Urine } \\
\text { Specimen }\end{array}$} & \multicolumn{3}{|c|}{ Urinary C.E.A. (ng/ml) } & \multirow[b]{2}{*}{$>110$} \\
\hline & & $<35$ & $35-60$. & $61-110$ & \\
\hline \multirow{3}{*}{$\begin{array}{l}\text { Female nurses } \\
\text { Females with } \\
\text { benign non-uro- } \\
\text { thelial disease }\end{array}$} & Random & $\begin{array}{l}13 \\
15\end{array}$ & Z & 1 & 1 \\
\hline & Midstream & 16 & 8 & 2 & - \\
\hline & Catheter & 7 & - & - & - \\
\hline
\end{tabular}

which contained less than $110 \mathrm{ng}$ of C.E.A. per $\mathrm{ml}$; seven of them also gave a catheter specimen, the values for which lay below $35 \mathrm{ng} / \mathrm{ml}$ (Table III).

The urinary C.E.A. levels in six out of eight women with proved active transitional cell carcinomas of the bladder were in excess of $110 \mathrm{ng} / \mathrm{ml}$ (random urine samples) (Table I), and three of these six tumours fell into stage T1. Two patients with successfully treated tumours of the bladder had levels below 35 $\mathrm{ng} / \mathrm{ml}$ (Table I).
Of the female patients with benign disorders or non-urothelial malignant tumours only one with essential hypertension and two with non-urothelial malignancy had C.E.A. levels in excess of $110 \mathrm{ng} / \mathrm{ml}$ (Table I). One patient had a malignant lymphoma which at necropsy was shown to be infiltrating the renal parechyma, while the other had extensive carcinoma of the cervix to account for the raised level. Both these patients had plasma C.E.A. levels of less than $12.5 \mathrm{ng} / \mathrm{ml}$, while four of the remainder in this group had values between $14 \mathrm{ng}$ and $84 \mathrm{ng} / \mathrm{ml}$.

\section{URINARY CONSTITUENTS AND C.E.A. LEVELS}

The presence in urine of contaminating bacteria, irrespective of their numbers or their type, did not influence the measured level of urinary C.E.A. However, eight patients with symptomatic urinary infection (four males and four females) had high levels similar to those found with carcinoma of the bladder (Table I). Urinary concentrates from two of these patients were submitted to Ouchterlony immunodiffusion analyses when a line of identity was obtained with authentic C.E.A. tested against goat anti-C.E.A. sera.

The presence of haematuria or glycosuria does not influence the apparent C.E.A. level. Also 37 female and 10 male control subjects had varying amounts of albuminuria; their range of urinary C.E.A. values fell within the same range as other controls.

\section{COMPARISON OF URINARY AND PLASMA C.E.A. LEVELS}

The plasma levels of C.E.A. in this series of patients are shown in Table IV. Seventeen of the $\mathbf{4 0}$ male and two of the $\mathbf{1 0}$ female patients with proved active bladder carcinomas had plasma levels in excess of $12.5 \mathrm{ng} / \mathrm{ml}$ (upper limit of normal); in only one, however, was the value in excess of the critical level of $40 \mathrm{ng} / \mathrm{ml}$ (Table IV) (Laurence et al., 1972).

There was no consistent correlation between urinary and plasma C.E.A. levels in the same patient. Of the 34 subjects in whom both values were assayed 7 had raised urine and plasma levels and 15 only high urine values, despite nine patients having T3 and T4 stage tumours. Of the remaining 12 patients 5 had raised plasma levels only and 7 had normal levels in both urine and plasma.

The plasma and urinary C.E.A. levels were available in 15 of the 16 patients with previously treated carcinomas who at the

TABLE IV-Plasma C.E.A. Levels in Male and Female Patients with Bladder Carcinoma

\begin{tabular}{|c|c|c|c|c|c|c|c|c|c|c|}
\hline & \multicolumn{8}{|c|}{ Plasma C.E.A. (ng/ml) } & \multirow{2}{*}{\multicolumn{2}{|c|}{$\begin{array}{l}\text { Incidence o } \\
\text { Positive } \\
\text { Assays }\end{array}$}} \\
\hline & \multicolumn{2}{|c|}{$<12.5^{*}$} & \multicolumn{2}{|c|}{$12 \cdot 5-20$} & \multicolumn{2}{|c|}{$21-40$} & \multicolumn{2}{|c|}{$<40$} & & \\
\hline & M. & F. & M. & F. & M. & F. & M. & F. & M. & F. \\
\hline $\begin{array}{l}\text { Carcinoma of bladder } \\
\text { Carcinoma of bladder plus infection } \\
\text { Previous carcinoma of bladdert }\end{array}$ & $\begin{array}{r}18 \\
5 \\
9\end{array}$ & $\begin{array}{l}6 \\
2 \\
-\end{array}$ & $\begin{array}{l}7 \\
5 \\
4\end{array}$ & $\frac{1}{2}$ & $\begin{array}{l}4 \\
-\end{array}$ & $\overline{1}$ & $\overline{1}$ & $\bar{z}$ & $\begin{array}{r}11 / 29 \\
6 / 11 \\
4 / 13\end{array}$ & $\begin{array}{l}1 / 7 \\
1 / 3 \\
2 / 2\end{array}$ \\
\hline
\end{tabular}

- Level of $12.5 \mathrm{ng}$ C.E.A./ml is taken as upper limit of normal (Laurence et al., 1972). + No clinical evidence of recurrent disease. 
time of the present study were regarded clinically as disease-free. All had normal urinary C.E.A. values (Table I) but six had minimally raised plasma values (Table IV). The future progress of these patients is being carefully followed, as these results may suggest the presence of local tumour undetected by cystoscopy and cytology or occult metastatic disease.

\section{Discussion}

This is the first time thai C.E.A. or C.E.A.-like material has been demonstrated in the urine of normal subjects and of patients with urothelial carcinomas. Its presence in urine is not too surprising in view of the common endodermal origin of the urinary bladder and gastrointestinal tract from which latter site and whose tumours C.E.A. was first isolated and thought to be "endodermal specific" (Gold and Freedman, 1965). Previous studies have shown that C.E.A. occurs in the plasma and faeces of healthy persons (LoGerfo et al., 1971; Moore et al., 1971; Freed and Taylor, 1972; Laurence et al., 1972) and is raised in association with a variety of malignant tumours and disorders associated with regeneration or inflammation or both (LoGerfo et al., 1971, 1972; Moore et al., 1971; Laurence et al., 1972; Reynoso et al., 1972; Zamchek et al., 1972).

From the results of the present series of urinary C.E.A. assays almost $70 \%(26 / 38)$ of subjects with active bladder carcinomas will be found to have raised levels, while normal levels occur in patients who have had successful removal of the tumour (Table I). In contrast to plasma C.E.A. levels which seem to be raised, particularly after local spread of all types of tumours, high urinary C.E.A. levels occurred in 7 out of 15 examples of $\mathrm{T} 1$ bladder carcinomas-that is, showing in-situ or early invasive tumours. Consequently, the assay of urinary C.E.A. appears to be clinically useful in the investigation of patients suspected of having urothelial carcinomas, possibly for the screening of the growing "high-risk" population in certain industries and for the detection of persistent or recurrent carcinoma after appropriate treatment.

In this respect, although assay of plasma C.E.A. levels has little to add in the early stages of carcinoma of the bladder, and does not seem to correlate with urinary levels, C.E.A. measure- ments in plasma and urine are both desirable in the follow-up phases, as plasma values may be raised in the presence of normal urinary levels and so possibly indicate extravesical spread. The more valuable role of urinary C.E.A. for bladder tumours probably is related to the fact that the urine is the immediate environment of the bladder mucosa and its papillary carcinomas. Certainly C.E.A. does not appear in the urine with most non-urothelial tumours even when the plasma level is raised unless such tumours involve the urothelium secondarily or increase the risk of cervical or vaginal contamination.

The possibility of contamination with genital tract secretions in females or in either sex with active urine infection must be borne in mind and excluded before any interpretation of C.E.A. data is made. Both factors can be largely eliminated by routine use of a midstream specimen of urine and its examination for cells and organisms if urinary infection is suspected.

Consequently we conclude from this preliminary data that the estimation of urinary C.E.A. or C.E.A.-like materials represents a further valuable application of this immunoassay in the diagnosis and care of patients suspected of having or with urothelial carcinomas.

We wish to express our gratitude to Professor T. Symington and Mr. David Wallace for their encouragement, and to the many clinicians who allowed patients to be studied in detail. These investigations were supported by the Medical Research Council (Grants 970/656/B and 971/817/B). One of us (R.R.H.) was in receipt of a Gordon Jacobs Research Fellowship.

\section{References}

Freed, D. L. J., and Taylor, G. (1972). British Medical fournal, 1, 85. Gold, P., and Freedman, S. O. (1965). Fournal of Experimental Medicine, 121, 439.

Laurence, D. J. R., et al. (1972). British Medical fournal, same issue

LoGerfo, P., Krupey, J., and Hansen, H. J. (1971). New England fournal of Medicine, 285 , 138 .

LoGerfo, P., LoGerfo, F., Herter, F., Barker, H. G., and Hansen, H. J. (1972). American fournal of Surgery, 123, 127.

Moore, T. L., Kupchik, H. Z., Marcon, N., and Zamchek, N. (1971). American fournal of Digestive Diseases, 16, 1.

Reynoso, G., et al. (1972). Fournal of the American Medical Association, 220, 361.

Zamchek, N., Moore, T. L., Dhar, P., and Kupchik, H. Z. (1972). New England fournal of Medicine, 286, 83.

\section{Interactions of Benzodiazepines with Warfarin}

\section{ORME, A. BRECKENRIDGE, R. V. BROOKS}

\section{Summary}

Administration of nitrazepam (10 $\mathrm{mg}$ nightly), diazepam (15 mg/day), and chlordiazepoxide (15 and $30 \mathrm{mg} / \mathrm{day}$ ) had no effect on steady-state plasma warfarin concentrations, the plasma half-life of warfarin, or anticoagulant control in patients and it appears safe to prescribe these agents to patients on long-term oral anticoagulants. Urinary excretion of $6 \beta$-hydroxycortisol, however, increased in two out of five patients given chlordiazepoxide. In rats

M.R.C. Clinical Pharmacology Research Group and Department of Clinical Pharmacology, Royal Postgraduate Medical School, London W.12

M. ORME, M.B., M.R.C.P., Honorary Senior Registrar

A. BRECKENRIDGE, M.B., M.R.C.P., Lecturer

Department of Chemical Pathology, St. Thomas's Hospital, London S.E.1

R. V. BROOKS, PH.D., D.SC., Reader in Chemical Pathology

pretreatment with chlordiazepoxide $(40 \mathrm{mg} / \mathrm{kg}$ for four days) caused stimulation of liver microsomal enzyme activity but neither diazepam nor nitrazepam had this effect.

\section{Introduction}

The subject of drug interactions has become very familiar to practising physicians. While a synergistic effect between drugs is widely used in therapeutics more stress is put on the adverse effects of multiple prescribing. This aspect has been widely studied in patients on long-term treatment with oral anticoagulants because such patients are frequently given other agents as part of their treatment and also because both the pharmacological effect and the plasma concentration of the oral anticoagulant can be measured, thus allowing the mechanisms of the interaction to be determined. Pronounced alteration of anticoagulant control in such patients is of obvious clinical importance. 